\title{
PENGARUH FREE CASH FLOW, LEVERAGE, PROFITABILITAS, LIKUIDITAS DAN UKURAN PERUSAHAAN TERHADAP KEBIJAKAN DIVIDEN
}

\author{
Andre Hand Prastya ${ }^{1}$, Fitri Yani Jalil ${ }^{2 *}$ \\ 1,2Universitas Islam Negeri Syarif Hidayatullah Jakarta \\ "Email: fitri.yani@uinjkt.ac.id
}

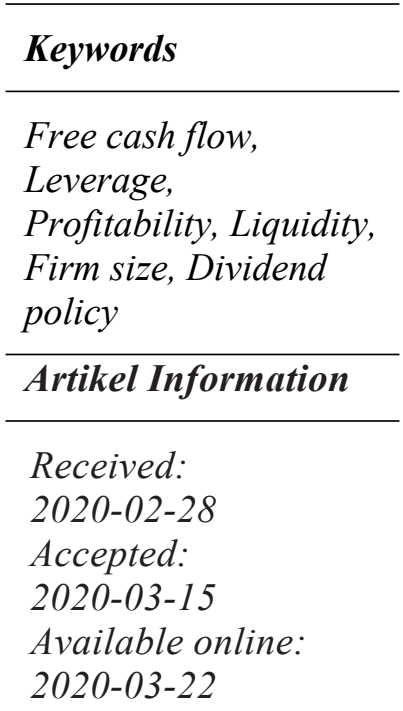

\begin{abstract}
The aim of this research is to find the effects of free cash flow, leverage, profitability, liquidity and firm size to dividend policy. This research using a sample of 21 LQ 45 companies registered in BEI 2015-2017. The method used is purposive sampling. Hypothesis testing in this research using multiple linear regression analysis. The result of this research show leverage, profitability, and firm size significantly affect the dividend policy. While free cash flow and liquidity have no effect on dividend policy

Abstract$$
\text { effect on dividend policy }
$$

\section{PENDAHULUAN}

Era globalisasi yang semakin pesat menciptakan peluang bisnis yang menjanjikan. Ini akan mendorong banyaknya perusahaan yang masuk ke pasar modal untuk mengambil peluang bisnis. Pada umumnya investor mempunyai tujuan utama untuk meningkatkan kesejahteraan dengan mengharapkan return atau keuntungan yang diperoleh dari investasi yang dilakukan. Return atau keuntungan yang akan diperoleh investor adalah dalam bentuk dividen maupun capital gain (Hardiatmo dan Daljono, 2013). Dividen merupakan bagian laba bersih perusahaan yang dibagikan kepada para pemegang saham sedangkan capital gain merupakan selisih positif antara harga perolehan saham dengan harga pasar saham. Dividen merupakan salah satu bentuk peningkatan wealth pemegang saham.

Dividen merupakan distribusi yang bisa berbentuk kas, aktiva lain, surat, atau bukti lain yang menyatakan utang perusahaan, dan saham kepada pemegang saham suatu perusahaan sebagai proporsi dari jumlah saham yang dimiliki oleh pemilik. Dividen akan dibagikan atau tidak, bagaimana sifat dan jumlah dividen merupakan masalah yang ditentukan 
oleh dewan direksi (Utama, 2012). Kebijakan dividen perusahaan tergambar pada dividen payout ratio, yaitu persentase laba yang dibagikan dalam bentuk tunai. Artinya, besar kecilnya dividen payout ratio akan mempengaruhi keputusan investasi para pemegang saham dan disisi lain juga akan berpengaruh terhadap kondisi perusahaan.

Jensen dan Meckling (1976) berpendapat bahwa umumnya pihak manajemen perusahaan akan menahan kas yang dimiliki untuk melunasi utang atau meningkatkan investasi. Namun hal ini tidak sejalan dengan pemegang saham yang mengharapkan dividen kas dalam jumlah relatif besar karena mereka sudah banyak menanamkan modal disana sehingga tentu saja ingin menikmati hasil investasi perusahaan tersebut.

Apabila perusahaan ingin menahan pendapatannya dalam bentuk laba ditahan, maka akan mengakibatkan dividen yang dibagikan semakin kecil. Investor lebih suka perusahaan membagikan laba dalam bentuk dividen untuk meningkatkan kesejahteraan mereka. Sebaliknya manajemen perusahaan juga harus memperhatikan keberlangsungan perusahaan dengan melakukan investasi yang berarti dividen yang dibagikan lebih kecil (Halviani \& Sisdyani, 2014). Hal ini menunjukkan adanya perbedaan kepentingan antara investor dengan manajemen perusahaan yang menimbulkan konflik keagenan.

Untuk mencapai kesejahteraan perusahaan dan para pemegang saham, maka diperlukan kebijakan-kebijakan yang dapat menyelaraskan kepentingan perusahaan maupun pemegang saham (Trisna dan Gayatri, 2019). Oleh sebab itu kebijakan dividen merupakan salah satu kebijakan krusial karena melibatkan banyak kepentingan dari pihak yang terkait.

Faktanya banyak perusahaan yang terdaftar di Bursa Efek Indonesia tidak semua perusahaan membagikan dividen kepada pemegang sahamnya. Hanya industri tertentu yang dapat membayar dividennya secara konsisten, walaupun dividen yang dibayarkan kepada pemegang saham mengalami perubahan setiap tahunnya (fluktuasi), padahal pihak investor lebih senang memperoleh kembalian investasi berupa dividen yang stabil. Hal tersebut disebabkan karena adanya pertimbangan-pertimbangan yang berbeda dalam membuat keputusan kebijakan dan pembayaran dividen dalam setiap perusahaan.

Perusahaan LQ 45 merupakan perusahaan yang dikenal dengan likuiditasnya yang tinggi, selain itu juga memiliki kinerja keuangan yang baik dan juga mempertimbangkan kapitalisasi pasar. Kedudukan perusahaan yang berada di dalam LQ 45 tidak bersifat tetap, setiap tiga bulan sekali dilakukan review pergerakan ranking saham-saham yang akan dimasukan kedalam perhitungan Indeks LQ 45 dan setiap enam bulan sekali ada penetapan kembali saham yang memenuhi kriteria serta mengeliminasi saham yang tidak memenuhi kriteria yang telah ditetapkan. 
Perusahaan yang berada di indeks saham LQ 45 yang listing di Bursa Efek Indonesia selama tahun 2015-2017 berjumlah 54 perusahaan, namun yang membagikan dividen tunai berturut-turut selama periode tersebut berjumlah 21 perusahaan. Bahkan masih ditemukan beberapa perusahaan yang terdatar di LQ 45 tahun 2015 sampai 2017 yang tidak membagikan dividen, hal ini diindikasikan karena perusahaan ingin meningkatkan kemampuan pembentukan dana internalnya. Mereka tidak membagikan dividen untuk mengurangi ketergantungan perusahaan terhadap dana eksternal sekaligus memperkecil risiko perusahaan.

Dengan demikian kebijakan dividen menjadi hal yang penting untuk dijadikan tolak ukur bagi investor dalam menanamkan modalnya disuatu perusahaan karena investor menginginkan pembagian dividen yang tinggi. Hal ini sesuai dengan bird in hand theory yang menyatakan investor menyukai pendapatan dividen yang tinggi karena pendapatan yang diterima seperti burung ditangan yang mempunyai nilai lebih tinggi dan risiko yang kecil dibanding capital gain. Teori ini juga berpendapat bahwa investor menyukai dividen karena kas ditangan lebih bernilai dibanding kekayaan dalam bentuk lain (Brigham dan Houston, 2012).

Berdasarkan fenomena yang ada, peneliti tertarik untuk memfokuskan masalah pada masih fluktuatifnya pembayaran dividen serta masih adanya perusahaan yang tidak membayarkan dividen dengan menghubungkan faktor-faktor yang berpengaruh terhadap kebijakan dividen. Penelitian ini akan mengidentifikasi beberapa variabel yang diduga berpengaruh terhadap kebijakan dividen yaitu free cash flow, leverage, profitabilitas, likuiditas dan ukuran perusahaan.

\section{PENGEMBANGAN HIPOTESIS}

\section{Free Cash Flow terhadap Kebijakan Dividen}

Free cash flow merupakan gambaran perusahaan dari arus kas yang tersedia untuk perusahaan dalam suatu periode akuntansi, setelah dikurangi dengan biaya operasional dan pengeluaran lainnya. Pembayaran dividen khususnya dividen tunai sangat tergantung pada posisi kas yang tersedia (Utama dan Gayatri, 2018). Semakin bertambah besarnya free cash flow yang ada dalam sebuah perusahaan, disinyalir perusahaan tersebut memiliki sejumlah kas yang tersedia untuk dibayarkan dalam bentuk dividen kepada para pemegang saham. Peningkatan free cash flow akan memberikan sinyal pada peningkatan dividen yang akan dibagikan pada para pemegang saham (Kafata dan Hartono, 2018).

Penelitian yang dilakukan oleh Paramita (2015) menunjukkan bahwa free cash flow berpengaruh signifikan terhadap kebijakan dividen. Perusahaan yang memiliki free cash flow 
memiliki kemungkinan besar untuk membagikan dividen. Pada saat suatu perusahaan memiliki aliran free cash flow, perusahaan dianggap mempunyai fleksibilitas keuangan yang memuaskan. Sehingga perusahaan yang memiliki free cash flow mempunyai kemungkinan besar membagikan dividen, hal ini bertujuan untuk mengurangi masalah keagenan yang mungkin terjadi karena penggunaan free cash flow. Penelitian lain yang dilakukan oleh Sari dan Budiasih (2016), Silaban dan Pengestuti (2017) serta Mangundap, Ilat, dan Pusung (2018) menyatakan bahwa free cash flow berpengaruh terhadap kebijakan dividen.

Sedangkan penelitian yang dilakukan oleh Arilaha (2009), Utama dan Gayatri (2018) serta Kafata dan Hartono (2018) memberikan hasil yang berlawanan yakni free cash flow tidak berpengaruh terhadap kebijakan dividen. Berdasarkan uraian yang telah dijelaskan, maka dirumuskan hipotesis sebagai berikut:

\section{$\mathrm{H}_{1}$ : Free cash flow berpengaruh signifikan terhadap kebijakan dividen.}

\section{Leverage terhadap Kebijakan Dividen}

Perusahaan dapat mengambil kebijakan untuk mendanai perusahaan melalui leverage. Leverage akan berdampak pada kebijakan dividen dalam perusahaan. Apabila perusahaan memiliki leverage yang besar maka perusahaan akan membagikan dividen lebih kecil. Hal ini disebakan karena keuntungan yang diperoleh perusahaan akan digunakan lebih dulu untuk melunasi utangnya (Trisna dan Gayatri,2019). Perjanjian utang jangka panjang biasanya juga disertai perjanjian utang yang melindungi kepentingan kreditur, sehingga kreditur akan membatasi pembayaran dividen.

Apabila perusahaan yang memiliki jumlah hutang yang besar maka biaya utang harus dikurangi melalui pengurangan utang. Untuk mengurangi jumlah utang dapat dilakukan dengan cara membiayai investasi yang bersumber dari dana internal sehingga akan menurunkan alokasi dividen kepada para pemegang saham (Arjana dan Suputra, 2017). Penelitian yang dilakukan oleh (Devi dan Erawati, 2014) menunjukan bahwa leverage berpengaruh terhadap kebijakan dividen, semakin besar utang yang dimiliki perusahan maka semakin kecil dividen yang akan dibagikan kepada investor. Penelitian lain yang dilakukan oleh Trisna dan Gayatri (2019) serta Sari dan Wiksuana (2018) menyatakan bahwa leverage berpengaruh signifikan terhadap kebijakan dividen. Namun penelitan yang dilakukan oleh Lestari dan Sulistyawati (2017) serta Ginting (2018) memberikan hasil yang berbeda, bahwa leverage tidak berpengaruh terhadap kebijakan dividen. Berdasarkan uraian yang telah dijelaskan, maka dirumuskan hipotesis sebagai berikut:

\section{$\mathrm{H}_{2}$ : Leverage berpengaruh signifikan terhadap kebijakan dividen.}




\section{Profitabilitas terhadap Kebijakan Dividen}

Profitabilitas adalah alat untuk mengukur seberapa besar efektivitas manajemen perusahaan dalam mengelola aset dan modal yang dimiliki perusahaan untuk menghasilkan laba bagi perusahaan. Semakin besar profitabilitas mensinyalir bahwa kinerja perusahaan semakin meningkat karena tingkat kembalian investasi (return) yang semakin besar, dengan demikian meningkatnya profitabilitas juga akan meningkatkan pendapatan dividen terutama dividen kas (Anggraini dan Wihandaru, 2015).

Arjana dan Suputra (2017) menyatakan bahwa profitabilitas perusahaan dapat dinilai melalui berbagai cara tergantung pada laba dan modal yang akan diperbandingkan satu dengan lainnya. Semakin tinggi tingkat laba maka semakin besar tingkat pembayaran dividen yang dibagikan kepada pemegang saham. Hal ini sesuai dengan signaling theory yang menjelaskan bahwa pihak manajemen akan membayarkan dividen untuk memberi sinyal mengenai keberhasilan perusahaan membukukan profit.

Penelitian yang dilakukan oleh Sari dan Wiksuana (2018), Silaban dan Pengestuti (2017) serta Apriliani dan Natalylova (2017) menunjukkan bahwa profitabilitas berpengaruh terhadap kebijakan dividen. Namun hasil penelitian yang dilakukan oleh Lopolusi (2013) serta Sari dan Budiasih (2016) menyatakan bahwa profitabilitas tidak berpengaruh terhadap kebijakan dividen. Berdasarkan uraian yang telah dijelaskan, maka dirumuskan hipotesis sebagai berikut:

\section{$\mathrm{H}_{3}$ : Profiitabilitas berpengaruh signifikan terhadap kebijakan dividen.}

\section{Likuiditas terhadap Kebijakan Dividen}

Likuditas merupakan kemampuan perusahaan dalam memenuhi kewajiban jangka pendeknya menggunakan seluruh aset lancar yang dimiliki sebelum jatuh tempo. Likuiditas merupakan faktor penting yang menjadi pertimbangan sebelum mengambil keputusan untuk menetapkan besarnya dividen yang akan dibagikan kepada para pemegang saham Lestari dan Sulistyawati (2017). Bagi perusahaan, dividen adalah arus kas keluar dan hal tersebut mempengaruhi posisi dari kas perusahaan. Semakin likuid sebuah perusahaan, kemungkinan pembayaran dividen yang dilakukan perusahaan tersebut akan semakin besar (Harun dan Jeandry, 2018).

Penelitian yang dilakukan oleh Hasana et al., (2017) menunjukkan hubungan yang signifikan terhadap kebijakan dividen. Dividen yang dibagikan kepada para pemegang saham dibayar dengan menggunakan kas yang dimiliki perusahaan. Semakin tinggi current ratio menunjukan semakin besar kemampuan perusahaan untuk melunasi kewajiban jangka 
pendeknya. Tingginya current ratio menunjukkan kepercayaan pemegang saham terhadap perusahaan untuk membayar dividen. Penelitian lain yang dilakukan oleh Sunarya (2013) dan Apriliani dan Natalylova (2017) menyatakan bahwa likuiditas berpengaruh terhadap kebijakan dividen.

Namun penelitian yang dilakukan oleh Lopolusi (2013) serta Yusman (2018) menyatakan bahwa likuiditas tidak berpengaruh terhadap kebijakan dividen. Berdasarkan uraian yang telah dijelaskan, maka dirumuskan hipotesis sebagai berikut:

\section{H4: Likuiditas berpengaruh signifikan terhadap kebijakan dividen.}

\section{Ukuran Perusahaan terhadap Kebijakan Dividen}

Ukuran perusahaan adalah gambaran perusahaan yang menunjukkan keberhasilan perusahaan yang dapat tercermin dari total aset yang dimiliki perusahaan. Perusahaan yang besar biasanya akan melakukan pembayaran dividen yang tinggi. Perusahaan yang besar lebih stabil dalam menghasilkan laba dibandingkan perusahaan kecil dan lebih mampu dalam memanfaatkan sumber daya yang dimilikinya. Perusahaan kecil biasamya memberikan pembayaran dividen yang lebih rendah, hal ini dikarenakan laba yang dihasilkan dialokasikan pada laba ditahan untuk menambah aset perusahaan (Devi dan Erawati, 2014).

Sebuah perusahaan yang besar dan mapan akan memiliki akses yang lebih mudah ke pasar modal, sedangkan perusahaan kecil lebih sulit untuk mengaksesnya. Kemudahan akses ke pasar modal dapat diartikan adanya fleksibilitas dan kemampuan perusahaan. Menurut Lopolusi (2013) semakin besar ukuran perusahaan maka omset yang dihasilkan juga semakin tinggi dan menyebabkan laba yang dihasilkan tingggi. Jika laba yang dihasilkan tinggi maka dividen yang akan dibagikan juga semakin tinggi. Penelitian yang dilakukan oleh Paramita (2015), Anggraini dan Wihandaru (2015) serta Apriliani dan Natalylova (2017) menyatakan bahwa ukuran perushaan berpengaruh terhadap kebijakan dividen.

Namun penelitian yang dilakukan oleh Elinda dan Sukirman (2015), Harun dan Jeandry (2018) menyatakan bahwa ukuran perusahan tidak berpengaruh terhadap kebijakan dividen. Berdasarkan uraian yang telah dijelaskan, maka dirumuskan hipotesis sebagai berikut:

\section{H5: Ukuran perusahaan berpengaruh signifikan terhadap kebijakan dividen.}

\section{METODE PENELITIAN}

Populasi yang digunakan dalam penelitian ini adalah semua perusahaan LQ 45 yang terdaftar di Bursa Efek Indonesia. Adapun periode yang diambil dalam penelitian ini adalah tahun 2015-2017. Metode penentuan sampel yang digunakan adalah purposive sampling, 
yaitu teknik penentuan sampel berdasarkan kriteria dan pertimbangan tertentu. Kriteria penarikan sampel yang digunakan adalah perusahaan LQ 45 yang konsisten membagikan dividen selama periode penelitian serta memiliki ketersediaan data variabel penelitian dari laporan keuangan selama periode 2015-2017.

Metode pengujian dalam penelitian ini terdiri dari: 1. Statistik Deskriptif. 2. Uji Asumsi Klasik (Uji Normalitas, Uji Multikolinearitas, Uji Auto Korelasi, Uji Heterokedastitas. 3. Uji Analisis Regresi Berganda (Uji f, Koefisien Determinasi dan Uji t).

\section{Operasional Variabel Penelitian}

\section{Kebijakan Dividen}

Kebijakan dividen merupakan suatu keputusan dimana laba yang didapat perusahaan apakah akan dibagikan pada para pemegang saham sebagai dividen atau akan ditahan yang berupa laba ditahan untuk selanjutnya digunakan dalam rangka pembiayaan investasi perusahaan dimasa mendatang (Kafata dan Hartono, 2018). Dalam penelitian Trisna dan Gayatri (2019) kebijakan dividen diukur dengan menggunakan Dividend Payout Ratio (DPR).

$D P R=\frac{\text { Dividend Per Share }}{\text { Earning perShare }}$

\section{Free Cash Flow}

Free cash flow dapat diartikan sebagai kas yang diperoleh dari selisih aktivitas operasi dengan capital expenditures yang oleh perusahaan dibelanjakan dengan tujuan memenuhi kapasitas produksi. Diskresioner ini dimanfaatkan perusahaan untuk melakukan akuisisi dan pembelanjaan modal yang berorientasi pada pertumbuhan, pembayaran hutang maupun dividen perusahaan (Sari dan Budiasih, 2016). Free cash flow perusahaan yang semakin tinggi, akan memberikan peluang bagi perusahaan untuk membayar dividen atau menahannya sebagai laba ditahan. Selain itu perusahaan yang mempunyai free cash flow lebih tinggi harus membayar lebih dividen untuk mengurangi biaya keagenan. Menurut Hasana et al., (2017) untuk mengukur free cash flow didapat dari cash from operation dikurang capital expenditure dibagi total aset.

$$
F C F=\frac{A K O-P M B-P M K}{\text { TotalAset }}
$$

\section{Leverage}

Leverage merupakan suatu ukuran yang menunjukkan bagaimana perusahaan menggunakan utang untuk mendanai pembiayaan investasi perusahaan. Semakin tinggi rasio 
leverage menunjukkan semakin besar pengguanaan utang yang mengakibatkan semakin besar pula risiko keuangan yang dihadapi oleh perusahaan yang akan mempengaruhi pembayaran dividen (Paramita, 2015). Menurut Argamaya dan Putri (2014) rasio yang digunakan untuk mengukur variabel leverage adalah debt to equity ratio (DER) dengan jenis skala yaitu skala rasio.

$$
D E R=\frac{\text { TotalUtang }}{\text { TotalModal }}
$$

\section{Profitbilitas}

Profitabilitas merupakan kemampuan perusahaan dalam memperoleh keuntungan (Ratih dan Damayanthi, 2016). Rasio ini juga memberikan ukuran tingkat efektivitas manajemen suatu perusahaan. Rasio profitabilitas digunakan untuk mengukur seberapa besar efektivitas manajemen perusahaan dalam mengelola aset dan modal yang dimiliki perusahaan untuk menghasilkan laba bagi perusahaan. Sari dan Budiasih (2016) dalam penelitiannya mengunakan return on asset untuk mengukur profitabilitas.

$$
R O A=\frac{\text { Earning After Tax }}{\text { TotalAset }}
$$

\section{Likuiditas}

Likuiditas menunjukkan kemampuan perusahaan mendanai operasional perusahaan dan melunasi kewajiban jangka pendeknya (Ginting, 2018). Semakin kuatnya posisi likuiditas suatu perusahaan maka akan makin besar kemampuannya untuk membayar dividen. Hal ini berarti bahwa makin kuat posisi likuiditasnya suatu perusahaan terhadap prospek kebutuhan dana diwaktu-waktu mendatang, akan makin tinggi rasio pembayaran dividennya Likuiditas dapat diproksikan dengan menggunakan rumus current ratio (Lismawati dan Suryanto, 2017).

$C R=\frac{\text { Total Aset Lancar }}{\text { TotalUtangLancar }}$

\section{Ukuran Perusahaan}

Ukuran perusahaan menggambarkan skala besar kecilnya perusahaan. Besar kecilnya usaha tersebut ditinjau dari lapangan usaha yang dijalankan (Anggraini dan Wihandaru, 2015). Penentuan skala besar kecilnya perusahaan dapat ditentukan berdasarkan total penjualan, total assets, rata-rata tingkat penjualan. Rumus menghitung besarnya ukuran perusahaan yaitu berdasarkan logaritma natural dari total aset (Paramita, 2015).

Firm $=$ Ln (TotalAset $)$ 


\section{HASIL DAN PEMBAHASAN}

Pada penelitian ini pengujian dilakukan menggunakan SPSS, dengan jumlah data 21 perusahaan LQ 45 periode 2015-2017.

\section{Uji Statistik Deskriptif}

Berikut ini adalah hasil uji statistik deskriptif yang dilakukan:

\section{Tabel 1}

\section{Statistik Deskriptif}

\begin{tabular}{lrrrrr}
\hline & N & \multicolumn{1}{c}{ Min } & \multicolumn{1}{c}{ Max } & \multicolumn{1}{c}{ Mean } & Std. Deviation \\
\hline FCF & 63 &,- 749 &, 583 &,- 085 &, 269 \\
DER & 63 &, 153 & 3,313 & 1,110 &, 810 \\
ROA & 63 &, 015 &, 458 &, 121 &, 109 \\
CR & 63 &, 482 & 6,913 & 2,139 & 1,408 \\
SIZE & 63 & 28,989 & 33,320 & 30,984 & 1,066 \\
DPR & 63 &, 036 & 1,386 &, 458 &, 287 \\
Valid N (listwise) & 63 & & & & \\
\hline
\end{tabular}

Sumber: Data sekunder yang diolah, 2019

Hasil statistik deskriptif pada variabel kebijakan dividen nilai minimum sebesar 0,036 sedangkan nilai maksimum 1,386 Nilai rata-rata (mean) kebijakan dividen sebesar 0,458 dan standar deviasi sebesar 0,287. Variabel free cash flow memiliki nilai minimum sebesar -0,749 sedangkan nilai maksimum 0,583. Nilai rata-rata (mean) free cash flow sebesar -0,085 dan standar deviasi sebesar 0,269. Variabel leverage memiliki nilai minimum sebesar 0,153, sedangkan nilai maksimum 3,313 Nilai rata-rata (mean) leverage sebesar 1,110 dan standar deviasi sebesar 0,810. Variabel profitabilitas memiliki nilai minimum sebesar 0,015, sedangkan nilai maksimum 0,458. Nilai rata-rata (mean) profitabilitas sebesar 0,121 dan standar deviasi sebesar 0,109. Hasil uji statistik variabel likuiditas memiliki nilai minimum sebesar 0,482, sedangkan nilai maksimum 6,913. Nilai rata-rata (mean) profitabilitas sebesar 2,139 dan standar deviasi sebesar 1,408. Hasil uji statistik variabel ukuran perusahaan memiliki nilai minimum sebesar 28,989, sedangkan nilai maksimum 33,320. Nilai rata-rata (mean) ukuran perusahaan sebesar 30,984 dan standar deviasi sebesar 1,066.

\section{Uji Asumsi Klasik}

Hasil uji asumsi klasik disajikan pada tabel-tabel berikut:

\section{Tabel 2}

Hasil Uji Normalitas

\begin{tabular}{llr}
\hline & & Unstandardized Residual \\
\hline $\mathrm{N}$ & & 63 \\
Normal Parameters & Mean &, 0000000 \\
& Std. Deviation &, 20116211 \\
\hline
\end{tabular}



PERUSAHAAN TERHADAP KEBIJAKAN DIVIDEN

\begin{tabular}{llr}
\hline Most Extreme Differences & Absolute &, 091 \\
& Positive &, 091 \\
& Negative &,- 066 \\
Test Statistic & &, 091 \\
Asymp. Sig. (2-tailed) &, 200 \\
\hline Sumber: Data sekunder yang diolah, 2019 &
\end{tabular}

Berdasarkan pada hasil uji Kolmogorov-Smirnov diketahui Asymp. Sig. (2-tailed) sebesar 0,200. Nilai tersebut lebih besar dari nilai signifikannya yaitu 0,05. Dengan demikian dapat disimpulkan bahwa data berdistribusi normal.

\section{Tabel 3}

\section{Hasil Uji Multikolonieritas}

\begin{tabular}{|c|c|c|c|}
\hline \multirow{2}{*}{\multicolumn{2}{|c|}{ Model }} & \multicolumn{2}{|c|}{ Collinearity Statistics } \\
\hline & & Tolerance & VIF \\
\hline \multirow[t]{6}{*}{1} & (Constant) & & \\
\hline & $\mathrm{FCF}$ & ,206 & 4,857 \\
\hline & DER & 697 & 1,434 \\
\hline & ROA & ,354 & 2,828 \\
\hline & $\mathrm{CR}$ & ,309 & 3,236 \\
\hline & SIZE & ,709 & 1,410 \\
\hline
\end{tabular}

Sumber: Data sekunder yang diolah, 2019

Tabel 3 menunjukkan bahwa nilai tolerance $>0,1$ dan VIF $<10$. Maka dapat disimpulkan bahwa variabel bebas dalam penelitian ini tidak saling berkolerasi atau dapat dikatakan tidak terjadi gejala multikolinearitas antar variabel.

\section{Tabel 4}

\section{Hasil Uji Heterokoedastisitas}

\begin{tabular}{|c|c|c|c|c|c|c|}
\hline \multirow[t]{2}{*}{ Model } & & \multicolumn{2}{|c|}{$\begin{array}{l}\text { Unstandardized } \\
\text { Coefficients }\end{array}$} & \multirow{2}{*}{$\begin{array}{c}\text { Standardized } \\
\text { Coefficients } \\
\text { Beta }\end{array}$} & \multirow[t]{2}{*}{$\mathrm{t}$} & \multirow[t]{2}{*}{ Sig. } \\
\hline & & $\mathrm{B}$ & Std. Error & & & \\
\hline \multirow[t]{6}{*}{1} & (Constant) &,- 266 &, 650 & &,- 409 & ,684 \\
\hline & FCF &, 012 & 148 &, 023 &, 082 &, 935 \\
\hline & DER &,- 044 &, 027 &,- 250 & $-1,637$ & 107 \\
\hline & ROA & ,119 & 279 & ,091 & ,426 & 671 \\
\hline & CR &, 005 & 023 &, 047 & 207 &, 837 \\
\hline & SIZE &, 014 &, 020 &, 105 & ,692 & ,492 \\
\hline
\end{tabular}

Sumber: Data sekunder yang diolah, 2019

Tabel 4 menunjukan bahwa keseluruhan variabel memiliki nilai signifikansi diatas 0,05 yang artinya tidak ada indikasi heteroskedastisitas dalam model regresi. 


\section{Tabel 5}

\section{Hasil Uji Autokorelasi}

\begin{tabular}{lr}
\hline & Unstandardized Residual \\
\hline Test Value &,- 00347 \\
Cases $<$ Test Value & 31 \\
Cases $>=$ Test Value & 32 \\
Total Cases & 63 \\
Number of Runs & 29 \\
Z &,- 887 \\
Asymp. Sig. (2-tailed) &, 375 \\
\hline
\end{tabular}

Sumber: Data sekunder yang diolah, 2019

Berdasarkan hasil pada tabel 5 diketahui probabilitas (Asymp. Sig. 2-tailed) sebesar 0,375 yang menunjukan bahwa nilai signifikansi lebih dari 0,05 . Dari hasil tersebut dapat disimpulkan bahwa model tersebut tidak mengalami masalah autokorelasi.

\section{Uji Hipotesis}

Hasil uji hipotesis disajikan pada tabel-tabel berikut:

\section{Tabel 6}

\section{Hasil Uji F}

\begin{tabular}{llrrrrr}
\hline Model & & $\begin{array}{c}\text { Sum of } \\
\text { Squares }\end{array}$ & df & \multicolumn{1}{c}{$\begin{array}{c}\text { Mean } \\
\text { Square }\end{array}$} & F & Sig. \\
\hline 1 & Regression & 2,613 & 5 &, 523 & 11,873 &, 000 \\
& Residual & 2,509 & 57 &, 044 & & \\
& Total & 5,122 & 62 & & & \\
\hline
\end{tabular}

Sumber: Data sekunder yang diolah, 2019

Dari tabel 6 dapat dilihat bahwa nilai F hitung sebesar 11,873 dengan nilai sig. sebesar 0,000. Hal ini menunjukkan bahwa nilai signifikansi $<$ alpha $(\alpha=0,05)$. Hal ini menunjukan bahwa model penelitian sudah fit.

\section{Tabel 7}

\section{Hasil Uji Koefisien Determinasi}

\begin{tabular}{llrrr}
\hline Model & R & R Square & Adjusted R Square & Std. Error of the Estimate \\
\hline 1 &, 714 &, 510 &, 467 &, 20979957 \\
\hline
\end{tabular}

Sumber: Data sekunder yang diolah, 2019

Berdasarkan Tabel 7 diketahui bahwa nilai Adjusted $R^{2}$ yang diperoleh sebesar 0,467. Ini berarti bahwa kebijakan dividen perusahaan LQ 45 yang terdapat di BEI dapat dijelaskan oleh variabel bebas yaitu free cash flow, leverage, profitabilitas, likuiditas dan ukuran perusahaan yang diharapkan sebesar $46,70 \%$. Sisanya $53,30 \%$ ditentukan oleh variabel lain seperti investment opportunity set, collateralizable asset, kepemilikan manjerial, kepemilikan institusi dan struktur modal yang tidak dianalisis dalam penelitian ini. 


\section{Tabel 8}

\section{Hasil Uji t}

\begin{tabular}{llrrrrr}
\hline Model & \multicolumn{2}{c}{$\begin{array}{c}\text { Unstandardized } \\
\text { Coefficients }\end{array}$} & \multicolumn{2}{c}{$\begin{array}{c}\text { Standardized } \\
\text { Coefficients }\end{array}$} & t & Sig. \\
\cline { 3 - 5 } & \multicolumn{1}{c}{ B } & Std. Error & \multicolumn{2}{c}{ Beta } & & \\
\hline 1 & (Constant) & $-1,974$ &, 957 & & $-2,063$ &, 044 \\
& FCF &, 371 &, 219 &, 347 & 1,698 &, 095 \\
& DER &,- 119 &, 039 &,- 334 & $-3,011$ &, 004 \\
& ROA & 1,447 &, 411 &, 549 & 3,521 &, 001 \\
& CR &, 018 &, 034 &, 088 &, 531 &, 598 \\
& SIZE &, 077 &, 030 &, 285 & 2,590 &, 012 \\
\hline
\end{tabular}

Sumber: Data sekunder yang diolah, 2019

Berdasarkan hasil pada Tabel 8 dapat disimpulkan bahwa variabel free cash flow (FCF) tidak berpengaruh signifikan secara parsial terhadap variabel kebijakan dividen dengan tingkat signifikansi 0,095 lebih besar dari 0,05. Variabel leverage (DER) berpengaruh signifikan secara parsial terhadap variabel kebijakan dividen dengan tingkat signifikansi 0,004 lebih kecil dari 0,05. Variabel profitabilitas (ROA) berpengaruh signifikan secara parsial terhadap variabel kebijakan dividen dengan tingkat signifikansi 0,001 lebih kecil dari 0,05. Variabel likuiditas (CR) tidak berpengaruh signifikan secara parsial terhadap variabel kebijakan dividen dengan tingkat signifikansi 0,598 lebih besar dari 0,05. Variabel ukuran perusahaan (size) berpengaruh signifikan secara parsial terhadap variabel kebijakan dividen dengan tingkat signifikansi 0,012 lebih kecil dari 0,05.

\section{PEMBAHASAN}

\section{Pengaruh Free Cash Flow Terhadap Kebijakan Dividen}

Dari Tabel 8 diperoleh bahwa free cash low memiliki t hitung 1,698 dengan tingkat signifikansi sebesar 0,095. Hal tersebut menunjukan bahwa tingkat signifikansinya di atas 0,05. Dengan demikian $\mathrm{H}_{1}$ ditolak, yang berarti free cash flow tidak berpengaruh terhadap kebijakan dividen.

Hasil penelitian ini mendukung penelitian yang dilakukan oleh Utama dan Gayatri (2018) yang menyatakan bahwa free cash flow tidak berpengaruh terhadap kebijakan dividen. Free cash flow saat ini belum menjadi perhatian bagi investor di Indonesia karena perusahaan yang ada tidak menyampaikan data mengenai free cash flow secara eksplisit sehingga belum mempengaruhi kebijakan dividen yang dilakukan oleh perusahaan. Hasil penelitian ini juga mendukung penelitian Arilaha (2009) yang menyatakan bahwa free cash flow tidak berpengaruh terhadap kebijakan dividen. Besar kecilnya arus kas bebas tidak mempengaruhi tinggi rendahnya pembagian dividen. Apabila perusahaan menginginkan untuk 
memaksimumkan kekayaan pemegang saham dengan membagikan dividen sedangkan kondisi arus kas bebas tidak memungkinkan, perusahaan dapat menggunakan pendanaan eksternal. Sejalan dengan pecking order theory yang mengemukakan bahwa perusahaan cenderung mengutamakan pendanaan internal guna membayar dividen bila kebutuhan dana kurang maka dapat menggunakan dana eksternal sebagai tambahannya. Namun hasil penelitian ini bertentangan dengan penelitian yang dilakukan oleh Sari dan Budiasih (2016) yang menyatakan bahwa free cash flow berpengaruh terhadap kebijakan dividen.

\section{Pengaruh Leverage Terhadap Kebijakan Dividen}

Berdasarkan hasil pada Tabel 8, hasil penelitian ini menunjukan bahwa leverage memiliki t hitung -3,011 dengan tingkat signifikansi sebesar 0,004. Hal tersebut menunjukan bahwa tingkat signifikansinya dibawah 0,05 . Dengan demikian $\mathrm{H}_{2}$ diterima, yang berarti leverage berpengaruh terhadap kebijakan dividen. Hasil penelitian ini konsisten dengan penelitian yang dilakukan oleh Trisna dan Gayatri (2019) yang menyatakan bahwa leverage berpengaruh terhadap kebijakan dividen. Kebijakan menggunakan utang yang tinggi dalam pembiayaan perusahaan menyebabkan kemampuan perusahaan untuk membayar dividen menjadi rendah, dikarenakan keuntungan perusahaan sebagian besar digunakan untuk pembayaran utang. Perusahaan yang memiliki tingkat utang yang rendah akan mengutamakan pembagian dividen yang lebih besar kepada pemegang sahamnya. Sebaliknya apabila perusahaan memiliki tingkat utang yang besar maka perusahaan akan lebih mengutamakan pemabayaran utangnya terlebih dahulu dibanding membagikan dividen sehingga dapat mencegah kebangkrutan perusahaan akibat tidak memenuhi kewajibannya kepada kreditur.

Hasil penelitian ini juga konsisten dengan penelitian yang dilakukan oleh Sari dan Wiksuana (2018) yang menyatakan bahwa leverage berpengaruh dan signifikan terhadap kebijakan dividen. Perusahaan yang mempunyai utang yang tinggi akan lebih tinggi dalam membayar bunga atas utang-utangnya, sehingga hal ini akan berdampak pada rendahnya laba yang menyebabkan rendahnya dividen yang diberikan kepada para pemegang saham. Hasil penelitian ini sejalan dengan pecking order theory yang menyatakan bahwa perusahaan menyukai internal financing (pendanaan dari hasil operasi perusahaan berwujud laba ditahan) daripada pendanaan dari luar. Namun penelitian ini tidak sejalan dengan penelitian yang dilakukan oleh Lestari dan Sulistyawati (2017) yang menyatakan bahwa leverage tidak berpengaruh terhadap kebijakan dividen. 


\section{Pengaruh Profitabilitas Terhadap Kebijakan Dividen}

Berdasarkan Tabel 8 hasil penelitian ini menunjukan bahwa profitabilitas memiliki $\mathrm{t}$ hitung 3,521 dengan tingkat signifikansi sebesar 0,001. Hal tersebut menunjukan bahwa tingkat signifikansinya dibawah 0,05 . Dengan demikian $\mathrm{H}_{3}$ diterima, yang berarti profitabilitas berpengaruh terhadap kebijakan dividen.

Hasil penelitian ini mendukung penelitian Arjana dan Suputra (2017) yang menyatakan bahwa profitabilitas berpengaruh terhadap kebijakan dividen. Semakin tinggi return on assets yang dimiliki perusahaan maka semakin tinggi pula dividen yang akan dibagikan. Semakin besar return on assets menunjukkan kinerja perusahaan yang semakin baik karena tingkat kembalian (return) yang semakin besar . Hal ini sesuai dengan signaling theory yang menjelaskan bahwa pihak manajemen akan membayarkan dividen untuk memberi sinyal mengenai keberhasilan perusahaan membukukan profit.

Hasil penelitian ini juga konsisten dengan penelitian yang dilakukan Sari dan Wiksuana (2018) yang menunjukkan bahwa profitabilitas berpengaruh terhadap kebijakan dividen. Dividen merupakan bagian dari keuntungan bersih perusahaan. Dividen akan dibagikan kepada pemegang saham jika perusahaan memperoleh laba. Laba perusahaan sangat mempengaruhi tingkat pembayaran dividen. Apabila perusahaan mengumumkan pembayaran dividen, maka investor akan menganggap kondisi perusahaan saat ini dan akan datang relatif baik. Hasil ini sesuai dengan the bird in the hand theory yang menyimpulkan bahwa investor akan senang dengan pendapatan pasti berupa dividen dari pada pendapatan yang belum pasti seperti capital gain. Namun penelitian ini tidak sejalan dengan penelitian yang dilakukan oleh Lopolusi (2013) yang menyatakan bahwa profitabilitas tidak berpengaruh terhadap kebijakan dividen.

\section{Pengaruh Likuiditas Terhadap Kebijakan Dividen}

Berdasarkan Tabel 8 hasil penelitian ini menunjukan bahwa likuiditas memiliki $\mathrm{t}$ hitung 0,531 dengan tingkat signifikansi sebesar 0,598. Hal tersebut menunjukan bahwa tingkat signifikansinya diatas 0,05 . Dengan demikian $\mathrm{H}_{4}$ ditolak, yang berarti likuiditas tidak berpengaruh terhadap kebijakan dividen.

Hasil penelitian ini konsisten dengan penelitian yang dilakukan oleh Lestari dan Sulistyawati (2017) yang menyatakan bahwa likuiditas tidak berpengaruh terhadap kebijakan dividen. Tidak adanya pengaruh yang signifikan dari likuiditas terhadap kebijakan dividen dikarenakan bahwa likuiditas yang besar pada perusahaan mencerminkan bahwa perusahaan tersebut memiliki banyak sumber aset yang dapat dikonversi menjadi kas yang berasal dari 
laba perusahaan. Komponen kas dalam aset lancar dapat menjadi sumber pendapatan bagi perusahaan. Sumber pendapatan tersebut tidak dibagikan dalam bentuk dividen dan sering kali dipergunakan untuk biaya operasional perusahaan. Atau bisa dikatakan laba lebih dioptimalkan untuk menjamin kelangsungan perusahaan, Sehingga kas yang besar tidak selalu digunakan untuk membayar dividen.

Hasil penelitian ini juga sejalan dengan penelitian yang dilakukan oleh Harun dan Jeandry (2018) yang menyatakan likuiditas tidak berpengaruh terhadap kebijakan dividen. Likuiditas perusahaan menunjukkan kemampuan perusahaan dalam mendanai operasional perusahaan dan melunasi kewajiban jangka pendeknya. Hasil analisis menunjukan bahwa tinggi rendahnya likuiditas perusahaan tidak berarti mempengaruhi besar kecilnya pembayaran dividen. Untuk itu perusahaan yang memiliki likuiditas yang baik tidak berarti pembayaran dividen lebih baik pula. Likuiditas tidak digunakan untuk membayar dividen tetapi untuk membayar kewajiaban jangka pendek sehubungan dengan pembelian aktiva tetap guna memanfaatkan kesempatan investasi dilihat dari semua perusahaan yang diamati sebagian besar mengalami peningkatan jumlah aktiva tetap setiap tahunnya. Namun penelitian ini bertentangan dengan penelitian Sari dan Suryantini (2019) yang menyatakan bahwa likuiditas berpengaruh terhadap kebijakan dividen.

\section{Pengaruh Ukuran Perusahaan Terhadap Kebijakan Dividen}

Berdasarkan Tabel 8, hasil penelitian ini menunjukan bahwa ukuran perusahaan memiliki t hitung 2,590 dengan tingkat signifikansi sebesar 0,012. Hal tersebut menunjukan bahwa tingkat signifikansinya di bawah 0,05 . Dengan demikian $\mathrm{H}_{5}$ diterima, yang berarti ukuran perusahaan berpengaruh terhadap kebijakan dividen.

Hasil penelitian ini mendukung penelitian Arjana dan Suputra (2017) yang menyatakan bahwa ukuran perusahaan berpengaruh terhadap kebijakan dividen. Ukuran perusahaan yang besar dan terus tumbuh bisa menggambarkan kemampuan perusahaan memperoleh laba yang tinggi sehingga menarik minat investor untuk menanam modal di perusahaan tersebut. Perusahaan besar mereka akan memiliki kecenderungan untuk membagikan dividen dalam jumlah tinggi untuk menjaga reputasi perusahaan di mata para investor. Sedangkan perusahaan kecil cenderung akan mengalokasikan laba yang diperoleh menjadi laba ditahan untuk meningkatkan aset perusahaan sehingga membuat perusahaan cenderung akan membagikan dividen yang rendah kepada investor.

Hasil penelitian ini juga konsisten dengan penelitian yang dilakukan oleh Harun dan Jeandry (2018) yang menyatakan bahwa ukuran perusahaan berpengaruh terhadap kebijakan 
dividen. Perusahaan yang besar dan mapan akan lebih mudah memasuki pasar modal dibandingkan perusahaan kecil. Hal ini akan berdampak pada kemudahan perusahaan untuk mendapatkan dana yang lebih besar sehingga perusahaan besar memiliki kemampuan yang lebih untuk membayar utang dan membayar dividen kepada pemegang sahamnya dibandingkan perusahaan kecil. Namun penelitian ini bertentangan dengan penelitian yang dilakukan oleh Elinda dan Sukirman (2015) yang menyatakan bahwa ukuran perusahaan tidak berpengaruh terhadap kebijakan dividen.

\section{SIMPULAN}

Penelitian ini bertujuan untuk menguji dan menganalisis pengaruh free cash flow, leverage, profitabilitas, likuiditas dan ukuran perusahaan terhadap kebijakan dividen pada perusahaan LQ 45 yang terdaftar di Bursa Efek Indonesia pada tahun 2015-2017. Data yang telah dikumpulkan dan telah di uji sebanyak 63 sampel dengan menggunakan uji regresi berganda. Dalam penelitian ini dapat diambil kesimpulan sebagai berikut: free cash flow tidak berpengaruh terhadap kebijakan dividen. Hasil penelitian ini konsisten dengan penelitian yang dilakukan oleh Utama dan Gayatri (2018) dan Arilaha (2009). Leverage berpengaruh terhadap kebijakan dividen. Hasil penelitian ini konsisten dengan penelitian yang dilakukan oleh Trisna dan Gayatri (2019) dan Sari dan Wiksuana (2018). Profitabilitas berpengaruh terhadap kebijakan dividen. Hasil penelitian ini konsisten dengan penelitian yang dilakukan oleh Arjana dan Suputra (2017) dan Sari dan Wiksuana (2018). Likuiditas tidak berpengaruh terhadap kebijakan dividen. Hasil penelitian ini konsisten dengan penelitian yang dilakukan oleh Lestari dan Sulistyawati (2017) dan Harun dan Jeandry (2018). Ukuran perusahaan berpengaruh terhadap kebijakan dividen. Hasil penelitian ini konsisten dengan penelitian yang dilakukan oleh Arjana dan Suputra (2017) dan Harun dan Jeandry (2018).

Penelitian ini diharapkan dapat memberikan referensi bagi manajer perusahaan dalam mengambil keputusan yang berkaitan dengan kebijakan dividen. Disamping itu penelitian ini diharapkan dapat memperkuat temuan-temuan dari penelitian sebelumnya. Bagi peneliti selanjutnya, penelitian ini diharapkan dapat dijadikan referensi serta dapat memberikan perbandingan dalam mengadakan penelitian terkait faktor-faktor yang dapat mempengaruhi kebijakan dividen.

Peneliti menyadari bahwa penelitian ini masih memiliki banyak keterbatasan dalam penelitian ini, yang antara lain sebagai berikut: Penelitian ini hanya menggunakan data keuangan Perusahaan LQ 45 selama 3 tahun (2015-2017) sehingga hasil penelitian hanya terbatas pada lingkup tersebut. Penelitian ini terbatas karena hanya menggunakan variabel 
free cash flow, leverage, profitabilitas, likuiditas dan ukuran perusahaan sebagai variabel yang mempengaruhi kebijakan dividen. Penelitian ini hanya menggunakan data keuangan selama 3 tahun (2015-2017).

Saran yang dapat peneliti berikan untuk peneliti selanjutnya dengan adanya ketebatasan-keterbatasan tersebut, antara lain sebagai berikut: menambah jumlah tahun penelitian sehingga hasilnya lebih handal, menggunakan objek perusahaan lain yang terdaftar di Bursa Efek Indonesia, menambah variabel-variabel independent seperti investment opportunity set, collateralizable asset, kepemilikan manjerial, kepemilikan institusi dan struktur modal yang diperkirakan dapat mempengaruhi kebijakan dividen.

\section{REFERENSI}

Arilaha, M. A. (2009). Leverage Terhadap Kebijakan Dividen. Jurnal Keuangan dan Perbankan, 13(1), 78-87.

Arjana, I. P. P. H., \& Suputra, I. D. G. D. (2017). Pengaruh Profitabilitas, Leverage, Ukuran Perusahaan dan Corporate Social Responsibility Pada Kebijakan Dividen Fakultas Ekonomi dan Bisnis Universitas Udayana (Unud), Bali , Indonesia Fakultas Ekonomi dan Bisnis. E-Jurnal Akuntansi, 21(3), 2021-2051. https://doi.org/10.24843/EJA.2017. v21.i03.p12

Brigham, E. F., \& Houston, J. F. (2012). Dasar-Dasar Manajemen Keuangan (5th ed.). Jakarta: Salemba Empat.

Elinda, F., \& Sukirman. (2015). Determinan Rasio Keuangan Terhadap Kebijakan Dividen. Accounting Analysis Journal, 4(4), 1-8. https://doi.org/10.15294/aaj.v4i4.9117

Fahmi, I. (2012). Analisis Laporan Keuangan. Bandung: Alfabeta.

Ginting, S. (2018). Pengaruh Likuiditas, Profitabilitas, dan Leverage Terhadap Kebijakan Deviden Pada Perusahaan LQ 45 yang Terdaftar di Bursa Efek Indonesia Periode 2012-2016. Jwem Stie Mikroskil, 8(2), 195-204.

Hardiatmo, B., \& Daljono. (2013). Analisis Faktor-Faktor yang Mempengaruhi Kebijakan Dividen (Studi Empiris Perusahaan Manufaktur yang Listing di Bursa Efek Indonesia Periode 2008 - 2010). Diponegoro Journal of Accounting, 2(1), 1-13.

Harun, S., \& Jeandry, G. (2018). Pengaruh Profitabilitas, Free Cash Flow, Leverage, Likuiditas dan Size terhadap Dividen Payout Ratio (DPR) Pada Perusahaan Manufaktur yang terdaftar di Bursa Efek Indonesia. Jurnal Riset Akuntansi, 5(2), 122137. https://doi.org/10.1017/CBO9781107415324.004

Jensen, M. C., \& Meckling, W. H. (1976). Theory of The Firm Manajerial Behaviour, Ageny Cost and Ownership structure. Journal of Financial Economics, 3(4), 305-360.

Kafata, A. A. A., \& Hartono, U. (2018). Pengaruh Free Cash Flow, Investment Opportunity 
Set, dan Return On Asset Terhadap Dividend Payout Ratio. Jurnal Ilmu Manajemen, $6(1), 1-9$.

Kasmir. (2010). Pengantar Manajemen Keuangan. Jakarta: Kencana.

Lestari, E., \& Sulistyawati, A. I. (2017). Kebijakan Deviden Pada Indeks Saham Lq45 Di Bursa Efek Indonesia. Jurnal Akuntansi Indonesia, 6(2), 113-130. https://doi.org/10.30659/jai.6.2.113-130

Lopolusi, I. (2013). Analisis Faktor-faktor yang Mempengaruhi Kebijakan Dividen Sektor Manufaktur yang Terdaftar di PT Bursa Efek Indonesia Periode 2007-2011. Jurnal Ilmu \& Riset Akuntansi, 2(1), 1-18. https://doi.org/10.1002/cbic.200800077

Sari, N. K. A. P., \& Budiasih, I. G. A. N. (2016). Pengaruh Kepemilikan Managerial, Kepemilikan Institusional, Free Cash Flow dan Profitabilitas Pada Kebijakan Dividen. E-Jurnal Akuntansi, 15(3), 2439-2466.

Sari, N. M. D. P., \& Wiksuana, I. G. B. (2018). Peran Profitabilitas dalam Memediasi Pengaruh Financial Leverage dan Investment Opportunity Set terhadap Kebijakan Dividen di BEI. E-Jurnal Ekonomi Dan Bisnis, 7(1), 143-176.

Sari, N. P. A. S. P., \& Suryantini, N. P. S. (2019). Pengaruh Profitabilitas, Likuiditas dan Tingkat Pertumbuhan Perusahaan Terhadap Kebijakan Dividen Pada Perusahaan Manufaktur. E-Jurnal Manajemen, 8(7), 4559-4588. https://doi.org/10.24843/ EJMUNUD.2019.v08.i07.p20

Trisna, I. K. E. R., \& Gayatri. (2019). Ukuran Perusahaan Memoderasi Pengaruh Free Cash Flow dan Leverage Terhadap Kebijakan Dividen. E-Jurnal Akuntansi, 26(1), 484-509. https://doi.org/10.24843/eja.2019.v26.i01.p18

Utama, N. P. S. P., \& Gayatri. (2018). Pengaruh Profitabilitas, Investment Opportunity Set dan Free Cash Flow Pada Kebijakan Dividen. E-Jurnal Akuntansi, 22(2), 976-1003. 